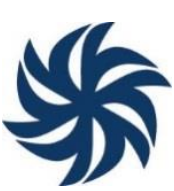

\title{
A AUTONOMIA FINANCEIRA DOS MUNICÍPIOS NO FEDERALISMO BRASILEIRO
}

\author{
THE FINANCIAL AUTONOMY OF THE MUNICIPALITIES IN BRAZILIAN \\ FEDERALISM
}

\section{LA AUTONOMÍA FINANCIERA DE LOS MUNICIPIOS EN EL FEDERALISMO BRASILEÑO}

\author{
Edith Maria Barbosa Ramos ${ }^{1}$ \\ Paulo Roberto Barbosa Ramos ${ }^{2}$ \\ Fernanda Dayane dos Santos Queiroz ${ }^{3}$ \\ Bruno Denis Vale Castro ${ }^{4}$
}

\begin{abstract}
Resumo: Desde 1787, quando os Estados Unidos da América (EUA) apresentaram ao mundo a organização da forma federativa de Estado, muitos outros países também a adotaram. Porém, é importante ressaltar que o federalismo não foi construído da mesma forma em todos os países. Pode-se dizer que existem características ditas essenciais, mas cabe a cada Estado, a depender de sua organização histórica, política e social determinar a forma própria de organização. No Brasil, adotou-se o federalismo cooperativo, com a constituição de três entes: União, Estados e Município, cuja a finalidade é garantir a autonomia dos entes federativos. Mas, no Brasil, a finalidade de um Estado autônomo ainda não foi
\end{abstract}

\footnotetext{
${ }^{1}$ Pós-Doutora em Direito Sanitário pela Fundação Oswaldo Cruz - FIOCRUZ/Brasília/DF. Doutora em Políticas Públicas pela Universidade Federal do Maranhão. Mestre em Direito pela Universidade Federal de Minas Gerais. Graduada em Direito pela Universidade Federal do Maranhão. Professora do Departamento de Direito da Universidade Federal do Maranhão. Professora e Vice-Coordenadora do Mestrado em Direito e Instituições do Sistema de Justiça da Universidade Federal do Maranhão. Coordenadora do Núcleo de Estudos em Direito Sanitário (NEDISA/UFMA). Professora e Pesquisadora da Universidade Ceuma. Bolsista do BEPP/FAPEMA (Bolsa de Estímulo à Produtividade em Pesquisa - Edital no 007/2018 - Produtividade). Membro Convidado da Rede IberoAmericana de Direito Sanitário.

${ }^{2}$ Graduado em Direito pela Universidade Federal do Maranhão (1992), Mestrado em Direito pela Universidade Federal de Santa Catarina (1997), Doutorado em Direito Constitucional pela Pontifícia Universidade Católica de São Paulo (2001) e Pós-Doutorado em Direito Constitucional pela Universidade de Granada - Espanha (2010/2011). Professor titular do Departamento de Direito da Universidade Federal do Maranhão, Coordenador do Núcleo de Estudos de Direito Constitucional dessa mesma instituição, Professor Pesquisador do Centro Universitário do Maranhão e Promotor de Justiça de Controle Externo da Atividade Policial do Ministério Público do Estado do Maranhão. Foi Bolsista Produtividade/FAPEMA.

3 Mestra em Direito da UFMA. Pós-Graduanda em Direito Público pela Universidade Estácio de Sá/CERS. Professora da Universidade Dom Bosco - UNDB. Advogada inscrita nos quadros da OAB/MA. Graduada em Direito pela Universidade Federal do Maranhão (UFMA - 2015). Integrante da Comissão de Bioética e Biodireito da OAB/MA. Integrou o Núcleo de Estudos em Direito Sanitário - NEDISA, vinculado ao Programa de Pós-Graduação em Direito e Instituições do Sistema de Justiça/UFMA.

${ }^{4}$ Doutorando em Ciências Jurídicas, Universidade Autónoma de Lisboa (UAL/PT). Mestre em Direito e Instituições do Sistema de Justiça, Mestrado em Direito da UFMA. Graduado em Direito pela Universidade Federal do Maranhão (UFMA). Membro efetivo do Núcleo de Estudos em Direito Constitucional - NEDC, coordenado pelo Prof. Dr. Paulo Roberto Barbosa Ramos. Assessor de Revisão Editorial da Revista do Curso de Direito da Universidade Federal do Maranhão. Assessor de Promotor de Justiça, lotado na 25 Promotoria de Justiça do Controle Externo da Atividade Policial (MPE/MA). Professor Universitário (Universidade CEUMA).
} 
atingida, tendo em vista que não há uma repartição de recursos adequada e a União, na realidade, permanece como a detentora de maior parte de competências administrativas e legislativas, assim como dos recursos arrecadados. Pretendeu-se, com a presente pesquisa analisar a efetivação das características do sistema federativo brasileiro, especialmente no que se refere à divisão de recursos a serem utilizados pelo município. Como metodologia, realizou-se abordagem qualitativa. No que diz respeito aos procedimentos técnicos, utilizou-se a pesquisa bibliográfica e documental.

Palavra-chave: Autonomia; Federalismo; Repartição de recursos.

Abstract: Since 1787, when the United States of America presented to the world the organization of the federative form of State, many other countries also adopted it. However, it is important to emphasize that federalism was not constructed in the same way in all countries. One can say that there are essential characteristics, but it is up to each state, depending on its historical, political and social organization to determine the proper form of organization. In Brazil, cooperative federalism was adopted, with the creation of three entities: the Union, the States and the Municipality, whose purpose is to guarantee the autonomy of the federative entities. But in Brazil, the purpose of an autonomous State has not yet been reached, as there is no adequate allocation of resources and the Union, in fact, remains the holder of most administrative and legislative powers, as well as the resources collected. It was intended, with the present research, to analyze the effectiveness of the characteristics of the Brazilian federal system, especially regarding the division of resources to be used by the municipality. As a methodology, a qualitative approach was carried out. With regard to technical procedures, bibliographical and documentary research was used.

Keywords: Autonomy; Federalism; Resources allocation.

Resumen: Desde 1787, cuando los Estados Unidos de América (EE. UU.) Presentaron al mundo la organización de la forma federativa de estado, muchos otros países también la adoptaron. Sin embargo, es importante tener en cuenta que el federalismo no se construyó de la misma manera en todos los países. Se puede decir que existen las llamadas características esenciales, pero depende de cada estado, dependiendo de su organización histórica, política y social, determinar su propia forma de organización. En Brasil, se adoptó el federalismo cooperativo, con la constitución de tres entidades: Unión, Estados y Municipio, cuyo propósito es garantizar la autonomía de las entidades federativas. Pero en Brasil, el propósito de un estado autónomo aún no se ha logrado, dado que no hay una asignación adecuada de recursos, y la Unión de hecho sigue siendo el titular de la mayoría de los poderes administrativos y legislativos, así como el recursos recaudados El objetivo de esta investigación fue analizar la efectividad de las características del sistema federativo brasileño, especialmente en lo que respecta a la división de los recursos que utilizará el municipio. Como metodología, se realizó un enfoque cualitativo. En cuanto a los procedimientos técnicos, se utilizó la investigación bibliográfica y documental.

Palabras clave: Autonomía; Federalismo; Intercambio de recursos. 


\title{
Introdução
}

O sistema federativo brasileiro possui características próprias. Desse modo, pretendese abordar algumas características e especificidades do federalismo brasileiro desde a sua incorporação pela Constituição de 1891 até os dias atuais.

Além desse breve retrospecto histórico, busca-se detalhar o federalismo cooperativo, trazido na Constituição de 1988, discutir sobre algumas das principais tipificações de federalismo existentes e por fim, a análise centra-se no histórico e características do ente federativo brasileiro mais próximo dos cidadãos, qual seja, o município.

O município é definido pela Constituição Federal como ente federativo político autônomo. Ressalta-se que em outros países que adotam a forma federativa de Estado, não há a figura de um terceiro ente autônomo. Na maioria das federações, o poder local é exercido por divisões administrativas das unidades federadas (União e Estados) que delegam diferentes graus de poder político, administrativo, econômico e social aos governos locais. O Brasil é a única federação no mundo que possui três níveis políticos autônomos definidos constitucionalmente (TOMIO, 2005).

Pretendeu-se, com a presente pesquisa, analisar a efetivação das características do sistema federativo brasileiro, especialmente no que se refere à divisão de recursos a serem utilizados pelo município, entendido como o ente mais próximo da sociedade, que deve ser o responsável, por exemplo, pelo fornecimento da saúde básica aos seus moradores, o não raro não ocorre por problemas conjunturais, analisados neste artigo.

Como metodologia, realizou-se abordagem qualitativa, devido ao vínculo essencial existente entre o material estudado e o tema em questão. Segundo Gustin (2013) a pesquisa com abordagem qualitativa estuda os dados buscando seu significado. Nesse contexto, tem-se como base a forma como se percebe o fenômeno do federalismo dentro do contexto do Estado brasileiro. Assim, ao utilizar a descrição qualitativa procurou-se analisar não só os aspectos aparentes do fenômeno como também seus aspectos formadores, buscando explicar sua origem histórica, relações e mudanças, e tentando intuir as consequências.

A pesquisa, quanto aos objetivos, foi desenvolvida de forma a buscar na bibliografia disponível o estado da arte da autonomia dos municípios e a divisão de recursos no Brasil. Para Gustin (2013, p. 24):

\begin{abstract}
A pesquisa qualitativa tem o ambiente natural como fonte direta de dados e o pesquisador como seu principal instrumento. Segundo os autores, a pesquisa qualitativa supõe o contato direto e prolongado do pesquisador com o ambiente e a situação que está sendo investigada via de regra, por meio do trabalho intensivo (GUSTIN, 2013, p. 24).
\end{abstract}

Diante desse quadro, o presente artigo tratou do fenômeno do federalismo brasileiro e a ideia de autonomia financeira dos municípios em relação ao direito à saúde. No primeiro momento, foi realizado um panorama geral do federalismo brasileiro, destacando suas 
peculiaridades históricas e estruturais, buscando-se compreender como ocorreu o processo de constituição dos entes federativos e a atual divisão de competências constitucionais.

Passo seguinte, investigou-se, de forma inicial, as relações e mudanças promovidas pelas diferentes constituições e legislações, realizou estudo bibliográfico sobre o tema, com o escopo de traçar pontos de fundamentais que configuram a divisão de recursos financeiros nos municípios brasileiros.

Em razão disso, com o escopo de contextualizar e analisar o fenômeno do federalismo, a presente investigação materializou-se no formato de revisão sistemática, enquanto espécie de revisão de literatura. Procedeu-se uma análise histórica e conceitual da ideia federalismo no contexto de atuação das diferentes unidades federativas brasileiras, objetivando compreender os determinantes que propiciaram sua constituição, bem como a atualização do seu processo de desenvolvimento. Portanto, este texto concentra-se em uma oportunidade, do ponto de vista científico, para aquele que pretende discutir o modelo de federalism1o brasileiro e em que medida a construção teórica sobre o tema possui envergadura para dar conta dar das consequências da divisão de recursos entre todos os entes da Federação.

Tal oportunidade justificou o esforço científico aqui materializado no percurso metodológico necessário para pôr em questão o seguinte a formação histórica dos municípios brasileiros e sua autonomia, bem como a engenharia de divisão de recursos orçamentários. Em razão disso, a presente pesquisa utilizou o método dedutivo, com a apropriação histórica de conceitos como federalismo, constitucionalismo, municípios e recursos orçamentos. Para o levantamento de informações, os principais procedimentos de coleta de dados foram bibliográficos e documentais (LAKATOS, 2008).

No que se refere à pesquisa bibliográfica, Gustin (2013, p. 40) destaca, em suma, que todo trabalho científico, toda pesquisa, deve ter o apoio e o embasamento na pesquisa bibliográfica, para que não se desperdice tempo com um problema que já foi solucionado e possa chegar a conclusões inovadoras.

Portanto, resta claro que a pesquisa bibliográfica não é uma simples catalogação de tudo o que já foi escrito a respeito do tema, mas sim uma busca minuciosa de informações para que se possa analisar de forma profunda o problema proposto, de modo que se chegue a uma resposta inovadora para o tema, mesmo que não seja uma resposta conclusiva, mas que sirva como meio para levar o leitor a refletir sobre a temática proposta.

Por seu turno, a análise documental é indispensável, na medida em que é realizada a partir de documentos, contemporâneos ou retrospectivos, considerados cientificamente autênticos. Desta feita, a análise documental constitui uma técnica importante na pesquisa qualitativa, seja complementando informações obtidas por outras técnicas, seja desvelando aspectos novos de um tema ou problema (LUDKE; ANDRÉ, 1986). Assim, entende-se que a pesquisa documental se caracteriza pela busca de informações em documentos que não 
receberam nenhum tratamento científico, com o objetivo de extrair informações neles contidas, a fim de compreender um fenômeno. Dessa forma, a presente investigação foi desenvolvida a partir de uma pesquisa bibliográfica e documental enquanto procedimentos que se utilizam de métodos e técnicas para a apreensão, compreensão e análise da literatura especializada e dos documentos selecionados, configurando-se, assim como pesquisa de índole eminentemente qualitativa.

\section{Conceituações e características dos sistemas federativos}

A De acordo com Schmitt (1992), a ideia central do federalismo encontra-se no pluralismo e na existência de autonomia política tanto para os estados-membros como para o Estado nacional, composto por entes federativos. O autor, em outra importante obra, denominada "O guardião da Constituição" (2007) trata sobre o conceito de federalismo. Vejase:

Com a palavra federalismo, procura-se expressar aqui apenas a justaposição e a cooperação, existentes dentro de uma organização federal de uma maioria de Estados encontra-se, aqui, uma pluralidade de formas estatais sobre base estatal (SCHMITT, 2007, p. 105).

De forma pormenorizada, Pereira (2015) traz como características principais do Estado Federal: ter ao menos, dois níveis de governo, constitucionalmente instituídos, sendo cada um dotado de autonomia um de nível federal, com jurisdição sobre todo o país e outro de nível regional ou subnacional; coexistência da soberania, como seu atributo; a terceira consiste na autonomia, inerente à unidade constitutiva, ou seja, o Estado; enumera-se também como característica o fato de possuir estruturas bicamerais ou duas Casas legislativas - uma formada pelos representantes do povo, outra formada pelos representantes das unidades federativas subnacionais - e, por fim, pode-se citar, a presença de um modelo democrático de estado de direito. Ainda sobre o tema, conclui Pereira (2015, p. 20) que somente torna-se possível a convivência entre a soberania e a autonomia, em virtude da descentralização de poder político e administrativo.

Ramos (2012) não considera que só pode ser chamado de federal a forma de estado que apresenta todas as características do federalismo americano, pois este não é o melhor, nem o único modelo existente, mas se faz importante por ter sido o primeiro modelo federalista. $\mathrm{O}$ autor afirma que qualquer sistema federal deve apresentar, na realidade, a maioria das seguintes características:

a) Constituição escrita e rígida; b) duas ordens jurídicas: central e parciais, sendo estas últimas dotadas de autonomia, quer dizer, competências próprias, possibilidade de auto-organização e de escolha de seus governantes e membros do poder legislativo, os quais terão competência para legislar sobre as matérias fixadas na constituição federal, além dos recursos necessários para fazer frente às suas responsabilidades; c) indissolubilidade do vínculo federativo; d) 
vontades parciais representadas na elaboração da vontade geral através do Senado Federal, que deve guardar isonomia dentre as vontades parciais; e) existência de um Tribunal Constitucional como guardião das competências e f) possibilidade de intervenção federal (RAMOS, 2012, p. 22).

De outro lado, Siqueira (2015, p. 31) é mais conciso ao apresentar as características principais para configuração de um Estado Federal, de forma que para ele, o sistema federal deve: possuir no mínimo dois níveis de governo, desde que todos os polos sejam detentores de autonomia; ter uma Constituição escrita; ter a possibilidade de intervenção federal e possuir uma Corte Suprema para dirimir os conflitos referentes a matérias constitucionais.

Compartilhando do entendimento de Ferreira (2010), entende-se que a concepção de Federalismo não pode ser pautada em um único e exclusivo modelo. Pelo contrário, a sua construção se dá com base na estrutura de cada Estado que o adota, não sendo possível atribuir um conceito generalizador, mas é possível a demonstração de características em comum em diversos contextos territoriais.

Pretende-se nas próximas seções fazer um breve aparato histórico, bem como apresentar características do federalismo brasileiro.

A inserção do sistema federalista no Estado brasileiro recebeu a influência do federalismo norte-americano. Honorio (2012) afirma que a forma de estado federativa contemporânea se assenta sobre as bases do modelo jurídico e político que a Europa começou a constituir na Baixa Idade Média e também durante as Revoluções Gloriosa, em 1688, Americana, em 1776 e Francesa, em 1789.

Sobre a forma de constituição da Federação nos EUA e no Brasil, Souza (2005) assevera que enquanto nos Estados Unidos da América, por meio da união das colônias, foi constituída a Federação, no Brasil ocorreu o contrário: o governo central subdividiu o poder que possuía entre as Províncias, que passaram a ser denominadas Estados, realizando a descentralização político-administrativa. Enquanto nos Estados Unidos houve a atuação de uma "força centrífuga", aqui no Brasil atuou a "força centrípeta" para a adoção do federalismo.

No Brasil, ao contrário do que ocorreu nos EUA, a metrópole portuguesa realizou colonização exploratória do país, com a extração das riquezas como o pau-brasil, inicialmente, e o ouro, em seguida. Havia também uma forte tributação e os portugueses, na condição de colonizadores, fizeram da Colônia, o seu Império, por quase 70 anos, quando, finalmente, através de um golpe de estado idealizado por militares, foi instaurada a República e, na sequência, para regular esse novo período, foi promulgada uma Constituição em 1891 trazendo a forma federativa de estado, nos moldes americanos. Sobre o cenário vivido, Pereira (2015, p. 28) relata: 
Com uma declaração de independência que derivava do poder central às antigas colônias, o quadro que se desenha no Brasil é de um Império com poder central vigoroso em detrimento de poderes locais quase anulados. Em tal cenário, é possível constatar duas importantes consequências: o empobrecimento constante das províncias em virtude da forte tributação em favor da Coroa e o enriquecimento demasiado da elite rural, a qual dominava o Poder Legislativo (já que o sufrágio e o direito de ser eleitos eram baseados no poder patrimonial), sendo beneficiada com a alocação dos recursos orçamentários (PEREIRA, 2015, p. 28).

Continua Pereira (2015) afirmando que por questões militares, religiosas, políticas e pela própria crise econômica, o Império não atendia mais aos anseios da sociedade, de forma que o ideal republicano crescia, assim como a ideia de adotar o modelo federalista, enquanto sistema de repartição política que contemplasse as entidades locais.

O Brasil foi por mais de 50 anos um Estado Unitário e Centralizador. Em 1824, D. Pedro I dissolveu a Assembleia Constituinte e outorgou a Constituição Imperial, de modo que o pensamento unitarista até hoje se mostra impregnado no imaginário popular. Pode-se dividir o período imperial em dois, levando-se em consideração a forma de centralização política. $\mathrm{Na}$ primeira fase, observa-se uma centralização absoluta do poder político, e na segunda, a partir do Ato Adicional de 1834, um processo de desconcentração administrativa. O Ato Adicional trouxe mudanças para o cenário político, tais como: conversão do Império do Brasil em uma monarquia federativa, Supressão do Conselho de Estado, Supressão do Poder Moderador, mas em 1841 houve redução da extensão dessas mudanças ${ }^{5}$. Segundo Santos e Andrade (2012, p. 9 10), embora tenha ocorrido retrocesso, a lei ainda é considerada um marco na instauração da descentralização política do país.

Bonavides (2004, p. 340), relata que as "sementes do federalismo foram deitadas ao subsolo político do Brasil na Revolução Pernambucana de 1817, ou seja, antes da Independência, no Projeto Antônio Carlos, em 1823”. Posteriormente, em 1831, o partido liberal mandou Projeto ao Senado para reformar a Constituição do Império e instalar no Brasil a Federação Monárquica, sendo esse projeto o que depois originou o Ato Adicional de 1834.

Bonavides (2004) coloca como um problema para a Federação brasileira o fato de o seu nascimento ter ocorrido em meio à ditatura, após um golpe de Estado militar desferido pelo Marechal Deodoro da Fonseca, no Campo de Santana. Nas palavras de Feijó (2012, p. 10):

\footnotetext{
${ }^{5}$ Conhecido como um contragolpe conservador no Ato Adicional (BONAVIDES, P; ANDRADE, P. 2006, p. 130)

${ }^{6}$ Trata-se do Projeto de Constituição para o Império do Brasil, que foi escrito por Antonio Carlos Ribeiro de Andrade e Silva e outros
} 
O regime federativo foi institucionalizado após o período monárquico, por intermédio do Decreto $\mathrm{n}^{\circ} 1$, assinado em 15 de novembro de 1889, com a Constituição de 1891, representando seu corolário institucional. Os partidários da República liberal procuraram, o quanto antes, convocar uma Assembleia Constituinte, já que nas palavras do então Ministro da Fazenda, Rui Barbosa, o novo Estado precisava de uma constituinte para que se fosse reconhecida a República e que os créditos necessários fossem obtidos. (FEIJÓ, 2012, p. 10).

A Constituição de 24 de fevereiro de 1891 previa a forma de governo, baseada no regime representativo e presidencialista, e a de estado, calcada na federação ${ }^{7}$, integrada pelas antigas Províncias erigidas a estados membros e pelo Distrito Federal, antigo Município Neutro:

Art. $1^{\circ}$ A Nação brasileira adota como forma de Governo, sob o regime representativo, a República Federativa, proclamada a 15 de novembro de 1889, e constitui-se, por união perpétua e indissolúvel das suas antigas Províncias, em Estados Unidos do Brasil. (BRASIL, 2017).

Art. $2^{\circ}$ Cada uma das antigas Províncias formará um Estado e o antigo Município Neutro constituirá o Distrito Federal, continuando a ser a Capital da União, enquanto não se der execução ao disposto no artigo seguinte. (BRASIL, 2017).

Assim, como aborda Feijó (2012, p. 16) o Estado federal brasileiro esforçou-se, desde a primeira constituição republicana, pela defesa da autonomia dos seus três entes. A concreta efetivação dessa autonomia revela-se, também, pela edificação de uma organização sistêmica, que pressupõe a atuação conjunta dos entes federativos, tendo em vista que a sua sobrevivência depende da solidariedade e da cooperação entre seus membros. A partir de uma atuação conjunta e coordenada em diversos setores (sociais, por exemplo), garante-se a unidade da nação, proteção a direitos, fomento e desenvolvimento de políticas públicas voltadas à sociedade.

Porém, como relata Souza (2005), o federalismo brasileiro foi uma fórmula "importada dos Estados Unidos", que foi incorporado pelo Brasil com a característica de possuir limitada autonomia dos seus estados membros, diferente do que apregoava os Estados Unidos. No Brasil, as Constituições estaduais são, em sua essência cópias da Constituição Federal, sendo pouquíssimo usadas, ocasionando a ocorrência de um "desvirtuamento do federalismo", que aborda a existência de equilíbrio entre o Poder Federal e os Poderes Estaduais.

Celso Furtado (1999, p. 50) afirma que "O federalismo precoce teria possivelmente inviabilizado o projeto de nação que justificou entre nós a permanência da Coroa portuguesa". No mesmo sentido, Santin et al. (2006) afirmam que não foram os estados que criaram a federação, mas o governo federal que passou a reconhecer a soberania, individualidade de cada província, pois o federalismo só existia na teoria. Observa-se, portanto, a partir do apresentado

\footnotetext{
${ }^{7}$ As demais Cartas Magnas brasileiras mantiveram o federalismo como forma de governo, até mesmo o Estado Novo em 1937; e em todas estas Constituições existiu a proibição expressa a qualquer tipo de vedação à forma federativa de estado.
} 
pelos autores acima expostos, que, na prática, a União concentrou o poder decisório nas suas mãos, transformando os estados em repetidores de normas da União e coadjuvantes no estado federal. Bonavides (2004, p. 324) afirma que:

Triste condição, essa, do sistema federal em nosso País: ele já nasceu enfermo e cresceu raquítico, eivado de contradições e impurezas centralizadoras que lhe desfiguraram a imagem; um federalismo açoitado de ameaças autocráticas e unitaristas geradoras de injustiças e ressentimentos. (BONAVIDES, 2004, p. 324).

Campos; et al (2012) sobre o contexto histórico em que foi inserido o federalismo brasileiro relata que tal como os norte-americanos, os federalistas no Brasil eram contrários à existência de uma Monarquia, pois com o controle da Metrópole, não poderia existir qualquer autonomia política das Províncias. Deste modo, começam a emergir movimentos de resistência, em Pernambuco, em 1824, na Bahia, em 1837, movimentos como a Inconfidência Mineira (1789) também foram importantes, pois visavam a formação de um país livre, utilizando-se de ideais iluministas.

Vê-se que o estado brasileiro é marcado por uma centralização de poder, enfraquecendo até mesmo o estado democrático, que necessita de maior proximidade com o povo para ter seus preceitos efetivados. A década de 1920 foi o palco da desagregação desse pacto político, visando reforçar o presidencialismo e fazendo do princípio federativo algo sem efetividade. Vivia-se a política do café com leite, em que os mais poderosos, que estavam situados no eixo São Paulo - Minas Gerais, eram aqueles que alternadamente se elegiam Presidentes da República.

Bonavides et al. (2006) questiona a existência de uma democracia liberal de alternância de poder, visto que um único partido de âmbito regional, durante quatro décadas, em um estado membro, elegeu 14 governadores e, em âmbito nacional, no mesmo lapso temporal, foi o responsável por eleger quatro Presidentes da República. Concluem os autores que "o federalismo no regime republicano da Carta Constitucional de 1891 era um federalismo verbal, com a igualdade dos entes federados existindo só no texto da Constituição" (BONAVIDES et al., 2006, p. 264).

Vê-se a grande discrepância entre o federalismo nos Estados Unidos e o federalismo brasileiro, desde a sua origem, até mesmo as constantes modificações em decorrência do momento político vivenciado. Nessa linha, Campos et al. (2012) elencam algumas dessas diferenças, tais como: no modelo americano, os estados eram dotados de soberania e autonomia política, enquanto que os estados membros brasileiros, com a política do café-com-leite, carregavam o caráter autocrático, com o revezamento do poder político apenas entre Minas Gerais e São Paulo. 
Em 1934 promulga-se a Constituição que visa fortalecer a autonomia dos estados membros e possui planos de descentralização administrativa, que se voltavam à valorização do município, mas havia nesse período forte apelo socialista dos mentores da Constituição, ocorrendo, na prática, a centralização e o engrandecimento dos poderes da União (NEME; et al, 2011, p. 131).

Traz Bonavides et al. (2006) que no Estado Novo, em 1937, a federação foi aniquilada. Os governos estaduais funcionaram como interventorias federais, com a presença forte da centralização e unitarismo da União. Ferreira (2003, p. 221) afirma que:

\footnotetext{
Desde que em 1930 desapareceu a Constituição de 1891, instituindo-se a ditadura, desfez-se o federalismo. Mantiveram-se geograficamente os Estados. Politicamente, conservaram este nome, mas perderam os seus poderes de administração autônoma, que passaram a exercer-se por delegados de confiança do presidente da República, sem a colaboração de câmaras ou assembleias (FERREIRA, 2003, p. 221).
}

Nesse período, o Estado Federal existia apenas no papel, pois na prática, as unidades territoriais (estados e municípios) antes descentralizadas, tiveram que se submeter ao poder fiscalizatório da União governada por Getúlio Vargas, com o poder político e econômico nas mãos dos coronéis e das famílias oligárquicas. Segundo Santos; Andrade (2012) com as modificações implantadas restabelecia-se o Estado Unitário em termos materiais.

Na década de 1940, as atenções do mundo voltaram-se para a II Guerra Mundial, em que segundo Santos e Andrade (2012) tratou-se de uma disputa pela ideologia política que iria predominar, se a do grupo dos Aliados, composta por Estados regidos pelo regime republicano democrático, ou do grupo do Eixo, composto por países (Alemanha, Itália e Japão) em que predominavam regimes totalitários. Dessa forma, com a queda dos países totalitários, o Brasil e o mundo tiveram que se adaptar à nova realidade. Com a Constituição de 1946 houve o necessário avanço em relação aos retrocessos do Estado Novo, com um estado social estruturado no bicameralismo clássico, com o sistema federativo restaurado, valorização dos estados membros, garantia de sua descentralização política, administrativa e capacidade tributária e restabelecimento da autonomia dos municípios (NEME et al., 2011).

Santos e Andrade (2012) citam como uma grande inovação trazida pela Constituição de 1946, o restabelecimento de uma cooperação financeira a fim de contribuir com o crescimento econômico de áreas mais subdesenvolvidas em nosso país através da criação da SUDENE (Superintendência de Desenvolvimento do Nordeste) e SPEVEA (Superintendência do Plano de Valorização Econômica da Amazônia) que eram descentralizações administrativas que recebiam incentivos financeiros para essa finalidade de crescimento econômico. Por conta da instituição dessas unidades houve no período da Constituição de 1946 a mudança do dualismo clássico para o cooperativo, pois se passou a dar maior importância ao 
desenvolvimento de áreas que possuíam problemas socioeconômicos e ecológicos e a instituir incentivos com capital proveniente das receitas da União, o que, posteriormente veio a interferir negativamente na autonomia dos Estados que recebiam tais incentivos.

Segundo Almeida $(1987$, p. 6) há uma boa base de ceticismo em relação ao futuro da Federação desde a Constituição de 1967, visto que é vivido, mais uma vez, o Estado unitário, apesar de mantido nominalmente o regime federativo.

Com a promulgação do Ato Institucional $\mathrm{n}^{\circ}$ 5, em 1968, foram conferidos ao Presidente da República muitos poderes, o que contribuiu para maior centralização de poderes políticos no âmbito da União. Com a Constituição de 1969, há grandes restrições aos planos e diretivas econômicos, com a superioridade da União frente aos demais entes do Estado (NEME, 2011). De acordo com Santos; Andrade (2012, p. 21) "o nome federalismo de integração, que recebeu essa forma federalista, representava a obsessão pela segurança nacional como forma de se institucionalizar uma maneira legítima de se centralizar o poder nas mãos de poucos".

Esse resgate perdura até a Constituição de 1988, onde é regulamentada a união indissolúvel dos estados e municípios e do Distrito Federal, a forma federativa de estado, a capacidade de auto-organização, autoadministração e autogoverno, que a Constituição possui um guardião (o Supremo Tribunal Federal - STF), enfim, são positivadas as diversas características do sistema federativo.

Porém, na prática, como traz Rocha (1997, p. 227), existe uma forma federativa muito distante do modelo norte-americano, há um federalismo tupiniquim, com a presença de "fenômenos políticos caboclos, intercalado, ou mesmo, impedido de se aperfeiçoar pelo coronelismo, da política de governadores e ditaduras militares”. Acrescenta-se ao cenário, a crescente corrupção, a criação de municípios por conveniência política, de forma que não se pode forjar um estado federativo no molde norte-americano, visto que se vivenciou no Brasil outra realidade histórica e desde a sua implantação, com tipificações diferentes adotadas, pode ser visualizada discrepâncias entre os dois modelos de federalismo.

No item seguinte pretende-se esclarecer o modo como o Brasil implanta o modelo federal no contexto atual.

\section{Os municípios como entes federativos dotados de autonomia}

O Brasil apresenta uma variante ao federalismo, que são os Municípios, com competências e recursos assegurados pela Constituição. Apresentam características como a autonomia, conforme visualiza-se a partir da leitura do artigo 30 da Constituição ${ }^{8}$, podem,

\footnotetext{
${ }^{8}$ Art. 30. Compete aos Municípios:

I - legislar sobre assuntos de interesse local;

II - suplementar a legislação federal e a estadual no que couber;

III - instituir e arrecadar os tributos de sua competência, bem como aplicar suas rendas, sem prejuízo da obrigatoriedade de prestar contas e publicar balancetes nos prazos fixados em lei;
} 
portanto, se auto organizar (visto que elaboram sua Lei Orgânica); possuem autonomia executiva, visto que elegem os prefeitos; e possuem ainda autonomia legislativa, pois legislam sobre matérias de interesse local, sobre arrecadação de tributos. Vê-se que eles coexistem lado a lado com a União Federal, os estados membros e as competências de ambos.

Por conta da presença desse ente federado, diz-se que a federação brasileira é sui generis, destoa de todos os demais estados federados (PIRES, 2005). Para Meirelles (1992, p. 26-27):

1 O Município, como unidade política administrativa, surgiu com a República Romana, interessada em manter a dominação pacífica das cidades conquistadas pela força de seus exércitos. Os vencidos ficavam sujeitos, desde a derrota, às imposições do Senado, mas, em troca de sua sujeição e fiel obediência às leis romanas, a República lhes concedia certas prerrogativas, que variavam de certos princípios privados (jus connubii, jus commercii etc.) até o privilegio político de eleger os seus governantes e dirigir a própria cidade (jus suffragii). As comunidades que auferiam essas vantagens eram consideradas Municípios (municipium) e se repartiam em duas categorias (municipia caeritis e municipia foederata), conforme a maior ou menor autonomia de que desfrutavam do Direito vigente (jus italicum). (MEIRELLES, 1992, p. 25).

2. O Município no mundo moderno diversificou-se em estrutura e atribuições, ora organizando-se por normas próprias, ora sendo organizado pelo Estado segundo as conveniências de nação, que lhe regula a autonomia e lhe defere maiores ou menores incumbências administrativas no âmbito local. O inegável é que, na atualidade, o Município assume enormes responsabilidades na ordenação da cidade, na organização dos serviços públicos locais e na proteção ambiental de sua área, agravadas a cada dia pelo fenômeno avassalador da urbanização que invade os bairros e degrada seus arredores com habitações clandestinas e carentes dos serviços públicos essenciais ao bem-estar dessas populações. (MEIRELLES, 1992, p. 26-27).

Sobre o significado da palavra, Tavares (1997, p.169) afirma que a palavra é formada por duas partículas, sendo a primeira munus ou munia, que significa muro, jurisdição, cercada, encargo, ofício e a segunda partícula o verbo capio, que possui o sentido de tomar. Dessa forma, conclui o autor que município é a jurisdição sobre a qual Roma tomou o encargo.

Manifestações de existência de uma divisão administrativa em âmbito local, existiu desde a Roma Antiga, porém o município, tal como disposto na Constituição de 1988 foi uma criação nacional. Ferreira (2010) narra que na Roma Antiga, ser um cidadão do município ou munícipe não era um direito de nascimento (diferentemente do que ocorria na Grécia), mas um

IV - criar, organizar e suprimir distritos, observada a legislação estadual;

V - organizar e prestar, diretamente ou sob regime de concessão ou permissão, os serviços públicos de interesse local, incluído o de transporte coletivo, que tem caráter essencial;

VI - manter, com a cooperação técnica e financeira da União e do Estado, programas de educação infantil e de ensino fundamental; (Redação dada pela Emenda Constitucional no 53, de 2006)

VII - prestar, com a cooperação técnica e financeira da União e do Estado, serviços de atendimento à saúde da população;

VIII - promover, no que couber, adequado ordenamento territorial, mediante planejamento e controle do uso, do parcelamento e da ocupação do solo urbano;

IX - promover a proteção do patrimônio histórico-cultural local, observada a legislação e a ação fiscalizadora federal e estadual. 
direito para poder desempenhar funções públicas locais.

Com o fim do feudalismo e surgimento dos estados absolutistas, Ferreira (2010, p. 35), utilizando em especial o exemplo de Portugal, afirma que o século XII foi um século de transformações, surgindo, em Portugal, o primeiro reino da Europa. No século VIII, a Península Ibérica foi invadida pelos árabes, houve guerras entre senhores feudais portugueses e invasores, de forma que muitas vilas ficaram sem seus senhores feudais, e os servos e vassalos começaram a se organizar em concelhos, dando origem à organização municipal portuguesa.

Vê-se, conforme assevera Ferreira (2010) que o surgimento do município em Portugal não ocorreu em decorrência de uma luta entre burgueses e nobreza, mas nasceu da necessidade do povo se organizar para reconquistar o seu território, que estava sendo invadido por árabes. Porém, uma padronização dos municípios só veio a ocorrer no século XV quando foram introduzidas diversas mudanças, como por exemplo, a criação do cargo de vereador, o direito de votar, dentre outras. De forma mais concisa, sobre esse momento histórico, relata Tavares (1997, p. 169):

\begin{abstract}
Com a insurreição da burguesia, começaram a aparecer as primeiras cidades livres na Europa. Na Inglaterra, desenvolveu-se o municipalismo desde 1450. $\mathrm{Na}$ Espanha, surgiram os ayuntamientos e, em Portugal, os Concelhos de Homens Bons, assembléias eletivas que governavam as cidades. A instituição das municipalidades portuguesas aparece já nas Ordenações Afonsinas (anteriores a 1512) e nas Manuelinas (de 1512). (TAVARES, 1997, p. 169).
\end{abstract}

O Brasil não possuía organização política durante os primeiros anos em que foi colônia de Portugal, pois interessava à Metrópole apenas a exploração do pau-brasil. Existiam, nesse momento histórico, as vilas de São Paulo e Piratininga, de acordo com Ferreira (2010). Mas, em meados do século XVI, após os espanhóis terem encontrado ouro em solo brasileiro, dividiu-se o território em quatorze capitanias hereditárias, entregando-as a particulares para que povoassem e explorassem as terras. Para tanto, foram criadas vilas, as quais deviam seguir as Ordenações Manuelinas, mas possuíam alguma autonomia para gerir suas finanças.

Santin et al. (2006, p. 62) afirmam, que "embora houvesse a divisão do território em capitanias, a centralização predominava na Colônia, de forma com que a expansão municipalista foi restringida". Porém, Ferreira (2010) traz que com o início do ciclo do ouro no século XVII, com as Ordenações Filipinas regendo as vilas da Colônia, a Coroa Portuguesa passou a impor e cobrar mais das câmaras locais tomando assim uma função mais centralizadora.

Em 1808, com a chegada da Família Real ao Brasil, o país passa a ter uma nova configuração administrativa, deixando de ser simplesmente uma colônia e passando a fazer parte do Reino Unido de Portugal, Brasil e Algarve. Com a independência do Brasil em 1822, e com a Constituição outorgada de 1824, o papel das câmaras municipais seria de administrar as vilas imperiais. Castro (2014) afirma que com a criação de Câmaras em todas as cidades e vilas 
existentes, bem como as que viessem a ser criadas, se denota uma preocupação com um poder local, que pudesse atender as demandas daquela população. Tavares $(1997$, p. 171) fala da posição dos futuros municípios:

A primeira referência constitucional do Brasil independente ao que futuramente se chamará Município está implícita no art. 22 daquela Constituição: 'O seu território é dividido em Províncias, as quais poderão ser subdivididas como o pedir o bem do Estado' - de que se pode inferir um processo de subdivisão administrativa como convinha ao estado unitário que então se estabelecia (...). Os poderes locais se constituíam em ameaça à unidade do Império, mas eram, reconhecidamente, os fulcros do desenvolvimento. Assim: o Imperador tinha, em cada Província, um Presidente nomeado e que podia remover, quando entender que assim convém ao bem do Estado (TAVARES, 1997, p. 171).

Em 1891 foi promulgada a primeira Constituição da República, a qual em seu artigo $68 \mathrm{diz}$ que os estados deveriam se organizar de forma que pudessem assegurar a autonomia dos municípios, sendo dever da União intervir nos estados somente em casos de invasões estrangeiras, ameaça à ordem federativa e para assegurar a execução das leis e recolhimento dos impostos federais. Porém, conforme aborda Rios (2014, p. 169) a palavra "município" é utilizada na Constituição Federal de 1891 apenas três vezes, para atribuir aos municípios uma relativa autonomia aplicável ao atendimento do peculiar interesse municipal. Atenta-se também para o fato de a Constituição não ter esclarecido o significado de "peculiar interesse", trazido em seu dispositivo, o que teria contribuído para que a autonomia local se tratasse de um mero dispositivo constitucional contribuindo para o fortalecimento do pacto Central.

A Constituição Federal de 1934 evidencia o enfraquecimento dos poderes regionais, pois havia descontentamento com a prática do coronelismo em âmbito regional e a população desejava exercer sua participação na vida política do país. Dessa forma, nesse período ocorre o fortalecimento do poder local, pois, conforme relata Rios (2014, p. 169): “o jogo político se materializa na arena municipal".

Porém, com o golpe de Getúlio Vargas e a instalação do Estado Novo, foi outorgada a Constituição de 1937, uma constituição autoritária, retirando dos estados e municípios sua autonomia, de modo que os prefeitos passaram a ser nomeados pelos interventores estatais que consequentemente eram nomeados pelo presidente.

Santin et al. (2006) relatam que a Constituição implantada em 1937 afetou gravemente a autonomia municipal nesse período, tendo em vista a centralização do poder nas mãos de Getúlio Vargas e a existência do sistema de interventorias em âmbito estadual e municipal.

No mesmo sentido, Rios (2014, p. 170) comenta que a "Carta de 1937 suspende os direitos atribuídos aos municípios, restringindo sua capacidade administrativa e centralizando o poder na figura do presidente. Inicia um período de nove anos, de um regime extremamente centralizador e intervencionista". 
Em 1946, após II Grande Guerra Mundial, é promulgada outra Constituição. Com ela, retomam-se as políticas e ideias descentralizadoras e democráticas, propiciando a autonomia dos municípios, de forma que passa a ter eleições para seus prefeitos e vereadores ${ }^{9}$ e que os estados somente poderiam intervir nos municípios para lhes regular as finanças ${ }^{10}$.

Sobre o tema, Rios (2014) diz que tanto os estados quanto os municípios passaram a ter um maior poder de organização de seus sistemas tributários, com a capacidade de gerenciar alíquotas e orçamentos. Porém, não se pode caracterizar a existência de uma autonomia financeira, pois não foram garantidos recursos tributários suficientes para seu autogoverno.

Em 1967, fruto dos ideais trazidos pelo golpe de 1964, surge uma nova Constituição, a qual, conforme aborda Ferreira (2010), teve um caráter extremamente autoritarista, ampliando o poder de intervenção da União nos estados e municípios.

Para Rios (2014), a Constituição Federal de 1967 surge em um dos períodos mais duros e conturbados da história do Brasil, possui medidas que caracterizam a centralização política em volta do Executivo Federal e, no que se refere aos estados e municípios, impõe severas restrições de autonomia. Sobre o período, Santin et al. (2006, p. 64). relatam:

\begin{abstract}
Todas as conquistas até então alcançadas pelos Municípios estavam sucumbindo, perdendo, assim, a autonomia anteriormente conquistada em tríplice aspecto: administrativo, financeiro e político com o ato institucional $\mathrm{n}^{\circ} 5$ e todos os demais que o seguiram. Assim, até a chegada da Constituição Cidadã de 1988, o Município teve reduzida e até extinta sua autonomia e autogovernabilidade em razão de inúmeros fatores históricos e governamentais. Todavia, a partir de 1988, conferiu-se ao Município sua característica maior: a autonomia e, no caso do federalismo brasileiro, faz o Município parte integrante da Federação, o que não ocorre nos demais Estados federados. (SANTIN et al.., 2006, p. 64)
\end{abstract}

No que diz respeito à Emenda Constitucional n. 1, de 1969, Castro (2014) afirma que ela não trouxe grandes modificações para os Municípios, aumentando apenas a centralização do poder nas mãos do Chefe do Executivo Federal e modificando o controle externo que era exercido apenas pela Câmara, e passou a ser exercido também pelo Tribunal de Contas do Estado ou de outro órgão estadual.

Em 1988, foi promulgada uma das mais avançadas Constituições já existentes no Brasil, no que se refere à solidificação da autonomia entre as esferas de governo e à participação popular. Por meio desta Constituição, reconhece-se a importância da esfera municipal na vida política do Brasil e institui-se a federação formada pelos entes: União, Estados, Distrito Federal e Municípios ${ }^{11}$. Rios (2014, p. 171) considera que entre as principais características da CF/88

\footnotetext{
${ }^{9}$ Artigo 28 da Constituição de 1946.

${ }^{10}$ Artigo 23 da Constituição de 1946.

${ }^{11}$ Assim versa o artigo $1^{\circ}$ da Constituição de 1988: A República Federativa do Brasil, formada pela união indissolúvel dos Estados e Municípios e do Distrito Federal. (...) e, no mesmo sentido, o artigo 18: A organização político-administrativa da República Federativa do Brasil compreende a União, os Estados, o
} 
encontra-se a ampliação do poder municipal no que tange ao processo de organização políticoadministrativa ${ }^{12}$. Dessa forma, o município passou a ser uma importante divisão federal com um alto grau de autonomia dotado de responsabilidades específicas e recursos próprios, possuindo também a prerrogativa de autogoverno.

Como exemplo, aborda-se que cabe à Câmara Municipal o poder de legislar, por meio da Lei Orgânica, sobre assuntos de interesses locais, como: tributação, organização dos serviços públicos, planejamento administrativo, infraestrutura, dentre outros.

Essa divisão deve-se, de acordo com Guerra (2015), à própria configuração em regime federativo, em que a descentralização objetiva o fortalecimento das capacidades de cada ente governamental em executar novas funções e interagir com as funções executadas pelas demais esferas, de modo que a descentralização permite melhor canalização das demandas sociais da população, mas é importante ressaltar que isso só ocorre em comunidades que estão mobilizadas na defesa de seus interesses.

Levcovitz et al. (2001), afirmam que a descentralização, por si, é insuficiente para a concretização dos princípios do SUS, como exemplo de serviço público prestado pelo Estado, soma-se à descentralização outros aspectos relevantes, como o adequado aporte financeiro, o fortalecimento da capacidade gestora nas três esferas de governo, a permeabilidade das instituições aos valores democráticos e apresentam como dificuldades, a imprecisão do papel do gestor estadual, com riscos de fragmentação do sistema e a acentuação de conflitos nas relações entre os gestores das esferas federal, estadual e municipal. A partir da Constituição de 1988 depreende-se que os municípios possuem capacidade de auto-organização, autogoverno, autolegislação, autoadministração.

Nesse ponto, discute-se a autonomia dos municípios no caso específico do federalismo brasileiro, de forma a trazer opiniões sobre o caráter meramente formal da autonomia no âmbito dos municípios, ou, pelo contrário, a existência de efetiva autonomia.

Santos e Andrade (2012) acreditam que o Município enquanto ente federativo é a maior proposição do modelo cooperativo e democrático de federalismo. O ente é o mais próximo do real titular do poder, devendo, portanto, ser capaz de atos políticos pensando em seus interesses locais $^{13}$. O autor firma, ainda, que a previsão dos Municípios como entes

Distrito Federal e os Municípios, todos autônomos, nos termos da Constituição.

12 Ferreira (2010, p. 43) afirma que: "Com certeza uma das grandes inovações da Constituição de 1988, foi a elevação do município para o status de ente federativo, sendo considerado por vários pensadores do mundo jurídico como um caso único e raro, sendo o Brasil o único país a adotar tal situação".

13 Sobre o sentido do município: "É na comuna que reside a força dos povos livre. As instituições comunais são para a liberdade aquilo que as escolas primárias são para a ciência; pois a colocam ao alcance do povo, fazendo-o gozar do seu uso pacífico e habituar-se a servir-se dela. Sem instituições comunais, pode uma nação ter um governo livre, mas sem possuir o espírito da liberdade. Paixões passageiras, interesse de um momento, o acaso das circunstâncias, podem dar-lhe as formas exteriores da independência, mas o despotismo encerrado no interior do corpo social cedo ou tarde aparece de novo à superfície" (Tocqueville, 2000, p. 54). 
federativos, aliados a ampliação das competências da União, fez com que os Estados se enfraquecessem e consequentemente perdessem gradativamente suas competências, tanto que atualmente os Estados são dotados de competências residuais, encobertas pelo vasto rol de competências da União e dos Municípios.

Mas alguns doutrinadores, como José Afonso da Silva (2000), não acolhem o entendimento de Município como ente federativo. Sustentam que o Município não é ente federativo ou mesmo que há absoluta inconsistência da tese de sua figuração na estrutura da federação, e outros, por outro lado, acreditam na integração da entidade local naquela estrutura. Aduz José Afonso da Silva (2000), argumentos como o de que o federalismo não possui o Município como elemento essencial; o da não-participação do município na formação da vontade e das decisões do Senado e na prestação jurisdicional; o da ausência de controle concentrado de constitucionalidade de leis municipais em face da Constituição da República; a vinculação direta dos Municípios à entidade regional ou intermediária, devido à existência de possibilidade de intervenção do Estado nos Municípios, o afastamento da vinculação dos entes locais à unidade federativa central, que é a União.

Em posição mitigada, coloca-se Ferrari (1993) o qual sustenta que a Federação brasileira passou por um processo diferente, relativo ao modelo federal dominante no mundo. Esse processo congrega a ordem jurídica central e as ordens jurídicas regionais: a União e os estados membros. Ferrari (1993, p. 62) vê no modelo brasileiro um arranjo peculiar:

[...] na Federação brasileira, conforme determina a Constituição Federal, os Municípios são unidades territoriais, com autonomia política, administrativa e financeira, autonomia essa limitada pelos princípios contidos na própria Lei Magna do Estado Federal e naqueles das Constituições Estaduais. (FERRARI, 1993, p. 62).

Nesse sentido, conclui-se que os municípios possuem competências presentes na própria Constituição, mas ainda assim, pode-se visualizar sujeição desse ente ao estado membro e à União quanto a princípios existentes na Constituição, por exemplo, trazidos pelo artigo $29^{14}$. Há ainda, dependência de outros fatores e entes para a criação, fusão e incorporação de municípios ${ }^{15}$.

Por outro lado, é inegável a necessidade de sua autonomia para possibilitar a gestão financeira dos recursos destinados ao município, visto que, conforme preleciona Souza (2005, p. 173) “esta é a esfera de poder em que o povo se encontra mais próximo, devendo possibilitar

${ }^{14}$ Art. 29. O Município reger-se-á por lei orgânica, votada em dois turnos, com o interstício mínimo de dez dias, e aprovada por dois terços dos membros da Câmara Municipal, que a promulgará, atendidos os princípios estabelecidos nesta Constituição, na Constituição do respectivo Estado e os seguintes preceitos: ${ }^{15}$ Art. $18 \S 4^{\circ}$ A criação, a incorporação, a fusão e o desmembramento de Municípios, far-se-ão por lei estadual, dentro do período determinado por Lei Complementar Federal, e dependerão de consulta prévia, mediante plebiscito, às populações dos Municípios envolvidos, após divulgação dos Estudos de Viabilidade Municipal, apresentados e publicados na forma da lei. 
aos governantes o contato direto com os problemas locais da comunidade, o que facilita soluções".

Conforme assevera Rabat (2002, p. 12): "Os municípios brasileiros tradicionalmente estão pouco dotados, tanto de aparelhamento administrativo, como de recursos financeiros".

Reverbel (2012) apresenta um pensamento que associa fortalecimento do Município, com aproximação de Estado Unitário e o fortalecimento dos estados membros como aproximação do Estado Federal, de forma a justificar que o Brasil está mais próximo de um Estado Unitário Centralizado ou mesmo de um Estado Unitário com pouca Descentralização ao poder local, Veja-se:

\begin{abstract}
A vida prática, a democracia, as políticas públicas são aplicadas nos governos locais. É o município que gera renda, circula mercadorias, administra e executa as políticas públicas. A vida existe no Município, nas famílias, nas comunidades locais. Assim, não existe governo central sem governo local, ao passo que todo governo local necessita de um mínimo de governo central. Os Estados Federativos vêm a ser a chave de toda a questão organizacional dos Estados. Ele na verdade é o justo meio, o meio-termo entre o governo central e o governo local [...]. O federalismo será mais fortemente descentralizado quando tirar competências da União, e mais fortemente centralizado quando tirar competências do Município em uma perspectiva de comparação entre estas duas forças [...]. Município forte está sinalizando um Estado Unitário. O federalismo acaba tirando a força do município, tendo ingerência, regulação, influência sobre ele. Por que não dizer, a federação de certa forma, anula as competências e os poderes do Município (REVERBEL, 2012, p. 126).
\end{abstract}

Ainda sobre o caráter meramente formal da autonomia dos Municípios, traz Almeida (1987) que a autonomia municipal carece de efetividade, faz-se necessário recursos financeiros para se tornar real. Nesse sentido, Ramos (2012, p. 60) afirma que o sistema federativo brasileiro possui como obstáculos para que seu federalismo seja referência mundial, grandes disparidades regionais, que tornam muitos entes dependentes da União, o que contribui para a ampliação do poder da União sobre os demais entes federativos, além disso, acrescenta-se a inexistência de uma cultura federalista no país, devido à falta de responsabilidade de muitos gestores públicos, com destaque para prefeitos de estados membros mais pobres, que muitas vezes se apropriam dos recursos públicos. Continua Ramos (2012) afirmando que a própria Constituição prevê uma alternativa, que consiste na regulamentação de matérias que a princípio pertencem ao poder central, mas que podem ser repassadas aos estados membros, quando necessário. Prevê ainda que Lei Complementar discipline o processo de cooperação entre o poder central e os estados membros e destes entre si, visando diminuir as desigualdades regionais.

Após todo o exposto, não resta dúvida quanto à intenção da Constituição de garantir o princípio federativo da descentralização, com vistas a fortalecer o poder local. No entanto, a decisão geral dos constituintes só se tornará praticamente efetiva na medida em que for 
acompanhada de uma preocupação de longo prazo com o fortalecimento do poder local.

Acontece que os municípios brasileiros não possuem muitos recursos financeiros próprios e, sem instrumentos concretos, "dificilmente alguma autonomia formal pode tornar-se substantiva" (RABAT, 2002, p. 12).

Silva (2000) afirma que seria impossível os municípios se tornarem entes federativos, vez que o conceito de federação seria a união de diversos estados sob o vínculo do pacto federativo, abrindo mão da soberania em favor de um Estado maior, de forma que teriam autonomia. Considera o caso brasileiro, um federalismo atípico, que surgiu de um caso raro de desagregação, imposto por uma Constituição, ao se realizar a mudança de Império para República.

Devido à instabilidade política, visualizada ao longo da história nacional, percebe-se que a União continuou centralizadora por muito tempo. Surge por parte de Ferreira (2010) um questionamento: o município tem condições de ser um ente federado? A resposta atribuída por Ferreira (2010) consiste no fato de que, tomando-se como exemplo o artigo 23, (que trata das competências comuns entre todos os entes federativos, em que todos têm a obrigação de cuidar e zelar pela saúde pública, por exemplo), quando o cidadão necessita de atendimento, irá recorrer ao ente federado mais próximo, ou seja, ao município, em desfavor de quem, em regra, irá litigar, em caso da não prestação do serviço. Soma-se ao cuidar e prestar a saúde, as outras diversas competências comuns e ainda as competências exclusivas que possuem. Assim, muitos municípios não têm condições de arcarem com todas as demandas utilizando-se de seus próprios recursos, de forma que a tendência é a existência de serviços cada vez mais deficientes.

No mesmo sentido Santin et al. (2006) tratam sobre o tema afirmando que deve existir a preocupação em melhorar o que está mais próximo de determinada comunidade, lugar onde realmente vivem os cidadãos e onde são sentidos efetivamente os problemas na prestação dos serviços públicos.

Mesmo com sua capacidade para tributar e arrecadar recursos, ocorre que a maioria dos recursos que sustentam os municípios são verbas oriundas da União e dos estados membros. Mesmo as grandes metrópoles brasileiras como São Paulo, por mais que arrecadem com seus tributos, é obvio que só estes não têm como sustentar a máquina pública, sendo, portanto necessária a complementação por meio de recursos federais e estaduais.

Outras problemáticas visualizadas no federalismo brasileiro se referem ao fato de que a gestão das rendas dos municípios modifica de acordo com o pensamento do legislador e ainda que "a maior parte do bolo das receitas tributárias" cabe à União. Sobre esse tema, preleciona Fabriz (2010, p. 89): 
No Brasil, apesar dos avanços que a Constituição de 1988 buscou imprimir ao tema, observa-se com facilidade a exaltação da unidade que, na maioria das vezes, não corresponde ao reforço da pluralidade. Não é de hoje que o poder central busca ser onipresente, expandindo suas forças de influência por todas as esferas de poder, sob o manto de guardião do desenvolvimento nacional. O Governo Federal com sua semissacralidade utiliza os meios de comunicação de massa para fixar uma imagem de proximidade, enquanto, na verdade, está distante quando a carência do povo exige medidas emergenciais (FABRIZ, 2010, p. 89).

Ferreira (2010) acredita que o desejo do legislador constituinte ao pensar a Constituição de 1988, seria o de inovar o conceito de federação criando-se um novo ente federativo, mas infelizmente o que acabou acontecendo foi a criação de uma anomalia jurídica.

Guerra (2015) complementa o entendimento trazido por Ferreira, ao afirmar que em municípios com menos de 20 mil habitantes (correspondente ao percentual de cerca de $75 \%$ dos municípios brasileiros), é difícil implantar um sistema de base municipal para serviços públicos, como a saúde, sem aumentar a fragmentação do sistema de atenção à saúde, o que propicia a ocorrência de ineficiências sistêmicas e problemas de má qualidade dos serviços.

É inegável que os municípios no Brasil dependem financeiramente dos Estados e da União. Acontecem, assim, jogadas políticas, de acordo com Ferreira (2010) em que os prefeitos, muitas vezes se tornam reféns de deputados, senadores, dentre outras figuras políticas, para a obtenção de recursos para suas respectivas administrações.

Pretende-se agora esclarecer de que forma ocorre a obtenção de recursos dos municípios. Primeiramente, insta realizar distinção de conceitos, como capacidade tributária, competência tributária, para finalmente tratar sobre a forma que ocorre a repartição de receitas.

A Constituição possibilitou aos municípios possuírem competência tributária, assim como capacidade tributária ativa. Insta não confundir os conceitos. Carvalho (2011, p. 270) define competência tributária como "uma das parcelas entre as prerrogativas legiferantes de que são portadoras as pessoas políticas, consubstanciada na possibilidade de legislar para produção de normas jurídicas sobre tributos", ou seja, é possibilidade que possuem os entes federados de editar leis que criem tributos. Por outro lado, a capacidade tributária ativa significa a investidura do poder de arrecadar, exigir determinado tributo. Vê-se que a capacidade tributária ativa para ocorrer precisa que o tributo tenha sido criado, ou seja, que o ente federado tenha exercido sua competência tributária.

Não bastava apenas dar aos entes federativos a possibilidade de criar seus tributos, por meio de lei, deve-se regulamentar a forma de efetivar a repartição de receitas. Pereira (2015) afirma que a repartição das fontes de receita figura como um recurso através do qual são estabelecidas normas de concessão de fontes de renda aos entes federativos. O Brasil adotou o critério de repartição de fontes de receitas através de competências privativas, em que apenas cada unidade federativa institui e cobra tributos a ela vinculados constitucionalmente. 
No caso dos municípios, eles podem instituir imposto sobre propriedade predial e territorial urbana; imposto de transmissão "inter vivos"; e o imposto sobre serviço de qualquer natureza. Podem também instituir taxas, em razão do exercício do poder de polícia ou pela utilização, efetiva ou potencial, de serviços públicos específicos e divisíveis, prestados ao contribuinte ou postos à sua disposição e ainda contribuições de melhoria, decorrente de obra pública que proporciona valorização do imóvel a ser tributado.

Além dessa fonte de recursos, os municípios também participam da distribuição de parcela do produto dos tributos auferidos. Essa fonte de recursos se refere ao repasse de receita tributária através de participação na arrecadação do tributo ou participação direta na arrecadação, a qual ocorre quando é previsto que determinada parcela do produto de uma unidade federativa pertence a outra. A Constituição determina que setenta e cinco por cento do imposto sobre operações de crédito, câmbio e seguro, ou relativas a títulos ou valores mobiliários cobrados sobre o ouro quando este é definido em lei como ativo financeiro ou instrumento cambial ${ }^{16}$; que cinquenta por cento do Imposto Territorial Rural instituído pela União pertence ao município em que a propriedade se encontra ${ }^{17} \mathrm{e}$ ainda o que delimita o artigo 158 da Constituição Federal ${ }^{18}$.

\footnotetext{
${ }^{16}$ Art. 153. Compete à União instituir impostos sobre:

$[\ldots]$

V - operações de crédito, câmbio e seguro, ou relativas a títulos ou valores mobiliários;

$[\ldots]$

$\S 5^{\circ}$ - O ouro, quando definido em lei como ativo financeiro ou instrumento cambial, sujeita-se exclusivamente à incidência do imposto de que trata o inciso $\mathrm{V}$ do "caput" deste artigo, devido na operação de origem; a alíquota mínima será de um por cento, assegurada a transferência do montante da arrecadação nos seguintes termos:

I - trinta por cento para o Estado, o Distrito Federal ou o Território, conforme a origem;

II - setenta por cento para o Município de origem.

${ }^{17}$ Art. 158. Pertencem aos Municípios:

[...]

II - cinquenta por cento do produto da arrecadação do imposto da União sobre a propriedade territorial rural, relativamente aos imóveis neles situados, cabendo a totalidade na hipótese da opção a que se refere o art. $153, \S 4^{\circ}$, III; 44 .

${ }^{18}$ Art. 158. Pertencem aos Municípios:

I - o produto da arrecadação do imposto da União sobre renda e proventos de qualquer natureza, incidente na fonte, sobre rendimentos pagos, a qualquer título, por eles, suas autarquias e pelas fundações que instituírem e mantiverem;

II - cinquenta por cento do produto da arrecadação do imposto da União sobre a propriedade territorial rural, relativamente aos imóveis neles situados, cabendo a totalidade na hipótese da opção a que se refere o art. $153, \S 4^{\circ}$,

III - cinquenta por cento do produto da arrecadação do imposto do Estado sobre a propriedade de veículos automotores licenciados em seus territórios;

IV - vinte e cinco por cento do produto da arrecadação do imposto do Estado sobre operações relativas à circulação de mercadorias e sobre prestações de serviços de transporte interestadual e intermunicipal e de comunicação.

Parágrafo único. As parcelas de receita pertencentes aos Municípios, mencionadas no inciso

IV, serão creditadas conforme os seguintes critérios:

I - três quartos, no mínimo, na proporção do valor adicionado nas operações relativas à circulação de mercadorias e nas prestações de serviços, realizadas em seus territórios;

II - até um quarto, de acordo com o que dispuser lei estadual ou, no caso dos Territórios, lei federal.
} 
Ao lado da repartição direta, tem-se a repartição indireta, que é a distribuição de receitas por meio da participação em fundos. A Constituição Federal de 1988, instituiu o fundo de Participação do Município - FPM ${ }^{19}$.

Nota-se, destarte, que a Constituição brasileira adotou um sistema misto de repartição de receitas, posto que as unidades federativas captam receitas tributárias por meio de fontes próprias, de participação direta na arrecadação de tributos e de participação indireta, por meio de fundos. Horta (1999) vê na repartição de competências, o centro de gravidade do poder federal. Vê-se que os Municípios recebem recursos oriundos da União, dos Estados e oriundos dos Fundos criados.

Siqueira (2015) aborda a existência de um desequilíbrio federativo, ocasionado pela dependência dos repasses e onerosidades da União, ente que acaba por pagar duas vezes pelo mesmo serviço, sendo uma vez quando repassa o recurso ao ente dependente e novamente quando, devido a não ocorrência da prestação do serviço de competência comum e concorrente, se vê obrigada a prestá-lo.

A problemática surge, porquanto, muitos municípios não instituem os tributos cabíveis, de forma que se tornam dependentes dos recursos a eles repassados. Sobre o tema, Ferreira (2010) afirma que o que se vê é um país no qual existem municípios que dependem dos recursos a eles repassados, um país no qual existe um ente federativo - o município -, que não tem representantes nas casas legislativas da União.

De acordo com Siqueira (2015), além da não ocorrência de instituição de tributos próprios pelos municípios, de forma a tornar os municípios dependentes de repasses diretos e indiretos, exige-se da União a prestação de serviços relativos às competências comuns e concorrentes. Considera o autor, portanto (SIQUEIRA, 2015) que os repasses legitimados pelo federalismo cooperativo brasileiro, acabam prejudicando a organização político-orçamentária do país, visto que estimulam a criação de municípios sem condições efetivas de sustentabilidade e que não criam tributos próprios, devido ao custo do processo de arrecadação.

Rabat (2002) considera que um problema a se destacar é que as rendas dos municípios ficam sujeitas às mudanças de perspectiva do legislador constituinte, seja do poder originário ou derivado.

Santos e Andrade (2012) se posicionam afirmando que o município é o primo pobre do federalismo brasileiro, tendo em vista a sua posição de inferioridade político-orçamentária que reveste sua contribuição ao Estado. O conceito trazido por Santos e Andrade é generalizador, uma vez que o federalismo brasileiro não é composto meramente por municípios pobres e dependentes. Conforme afirma Siqueira (2015), existem municípios dependentes de

${ }^{19}$ Art. 159. A União entregará:

I - do produto da arrecadação dos impostos sobre renda e proventos de qualquer natureza e sobre produtos industrializados quarenta e oito por cento na seguinte forma:

b) vinte e dois inteiros e cinco décimos por cento ao Fundo de Participação dos Municípios; 
recursos os quais, por conseguinte, provocam uma indevida onerosidade a muitos municípios vizinhos, que acabam por prestar serviços públicos que o município dependente não possui, o que ocasiona utilização de recursos próprios e das transferências recebidas de repasses da União e do Estado. Conclui Siqueira (2015, p. 111) que "estabelece-se uma verdadeira cadeia de entes dependentes, que se retroalimenta continuamente e compromete de maneira quase irreversível o equilíbrio do pacto federativo". Continua o autor, afirmando que ocorre no Brasil uma descentralização dependente, visto que os entes descentralizados não possuem capacidade de exercer a autonomia em sua plenitude, ocasionando a existência de uma federação centralizada (SIQUEIRA, 2015).

Siqueira (2015) utiliza o termo descentralização da legislação tributária e considera que ela ocasiona desequilíbrio na federação, por exemplo, devido à ocorrência de disputas de interesses entre os Estados e Municípios que, visando atrair investimentos e obter maior arrecadação, concedem incentivos fiscais que não atendem ao preceito da lealdade federativa, ocasionando o que se denomina "guerra fiscal".

Vê-se, de acordo com o que afirma Fabriz (2010), que técnicas de equilíbrio constitucional podem ser relacionadas às atividades financeiras existentes entre os membros do corpo federativo, pois quando ausentes as condições financeiras, estará o sentimento federativo como algo vazio, e o modelo federativo não passará de simples forma sem conteúdo.

\section{Conclusão}

Ao analisar o município, depreende-se que a Constituição de 1988 atribuiu a ele a capacidade de se auto organizar, autogovernar, criar suas próprias leis e se auto administrar, todavia, ainda assim, é possível visualizar sujeição desse ente ao Estado e à União, a por exemplo da criação de novos municípios, a ser feito por lei estadual, após consulta prévia, mediante plebiscito às populações dos municípios envolvidos. Porém, considera-se que essa previsão constitucional é uma espécie de proteção dada ao estado federal para que não haja criação de municípios que visem favorecer interesses políticos e de uma classe, que não possuam capacidade de criar e gerir seus tributos, transformando-se em meros municípios sanguessugas, autônomos apenas formalmente e de fato dependentes dos repasses dos demais entes, com serviços cada vez mais deficientes e com a Federação cada vez mais centralizada (RABAT, 2012).

Deveria ser o município o local em que cidadãos pudessem perceber efetivamente o funcionamento dos serviços públicos, porquanto, ele é o ente mais próximo do cidadão, local primeiro a que recorrem às pessoas que buscam cuidados em saúde, educação efetivação de políticas públicas, sendo também o local em que são primeiramente sentidos os problemas na prestação dos serviços públicos. 
Porém, mesmo com a sua capacidade para arrecadar tributos, a maioria dos recursos que sustentam os municípios brasileiros são provenientes da União e dos estados-membros, o que se deve à própria estrutura do federalismo brasileiro. Conclui-se dessa forma que, se a União concentra a maior parte das receitas, devido à forma como foi estruturado o federalismo brasileiro, retira-se dos municípios e até mesmo dos estados, a capacidade de racionalidade na execução dos serviços e políticas públicas que devam ser desenvolvidas nesses espaços.

Desse modo, faz-se necessária a realização de repasses de recursos para utilizar, manter e implantar as políticas sociais, sob pena de ocorrência de completo caos no âmbito das políticas públicas sociais.

Após toda a abordagem, observa-se que o federalismo brasileiro não é de fato uma anomalia, tal como afirmou Ferreira (2010). Acredita-se que o município, por ser o ente mais próximo da população, por ter para si competências próprias e ainda partilhar de competências comuns, deveria arrecadar maiores recursos para utilizar em prol do povo, devendo essa arrecadação ocorrer respeitando-se os preceitos do federalismo cooperativo, que apregoa a ajuda mútua dos entes federados.

Preza-se pela existência de proporcionalidade entre os deveres e prestação efetiva de serviços públicos pelos entes federados, além disso, é importante a existência de fiscalização efetiva e adequada arrecadação de tributos para que o federalismo cooperativo brasileiro prospere.

\section{Referências}

ALMEIDA, Fernanda Dias Menezes de. Considerações sobre os rumos do Federalismo nos Estados Unidos e no Brasil. Revista de Informação Legislativa, Brasília, ano 24, n. 96, p. 57 64, out./ dez. 1987.

BRASIL. Constituição da República Federativa do Brasil. Disponível em: http://www.planalto.gov.br/ccivil_03/leis/L5172.htm. Acesso em: 20 de mar. 2017.

CAMPOS, Mariano Henrique Maurício de; OLIVEIRA, Issac Antônio de. Federalismo de cooperação como cláusula pétrea: a relação entre a fragmentação do poder constituinte e o princípio democrático. Biblioteca Virtual do Ministério Público do estado de Minas Gerais, Repositório Institucional, 2012. Disponível em: https://aplicacao.mpmg.mp.br/xmlui/bit stream/handle/123456789/1201/FEDERALISMO\%20DE\%20COOPERA\%C3\%87\%C3\%830 $\% 20 \mathrm{COMO} \% 20 \mathrm{CL} \% \mathrm{C} 3 \% 81$ USULA\%20P\%C3\%89TREA.pdf?sequence $=1$. Acesso em: $20 \mathrm{de}$ fev. 2017.

BONAVIDES, Paulo. A Constituição aberta: Temas políticos e constitucionais da atualidade, com ênfase no Federalismo das Regiões. 3 ed. São Paulo: Malheiros, 2004.

BONAVIDES, Paulo; ANDRADE, Paes de. História constitucional do Brasil. 8 ed. Brasília: OAB Editora, 2006.

CARVALHO, Paulo de Barros. Curso de direito tributário. 23. ed. São Paulo: Saraiva, 2011. 
CASTRO, Gina Gouveia Pires de. Controle de Constitucionalidade de Lei e ato normativo Municipal: uma análise sobre seu funcionamento na Federação Brasileira. Dissertação.

(Mestrado em Direito). Universidade Federal de Pernambuco, Programa de Pós-Graduação em Direito, Recife, 2014.

FABRIZ, Daury Cesar. Federalismo, municipalismo e direitos humanos. Revista do Tribunal de Contas do Estado de Minas Gerais, Minas Gerais, v. 77, n. 04, ano XXVIII, out./nov./dez. 2010.

FEIJÓ, Alexsandro Rahbani Aragão. A Constituição brasileira de 1981 e o federalismo norte-americano. In: CONPEDI. (Org.). Sistema Jurídico e Direitos fundamentais individuais e

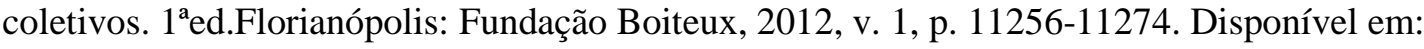
http://www.publicadireito.com.br/artigos/?cod=e00da03b685a0dd1. Acesso em: 30 de jan. 2017.

FERRARI, Regina Maria Macedo Nery. Elementos de direito municipal. São Paulo: Revista dos Tribunais, 1993.

FERREIRA, Patrésio Camilo. Federalismo brasileiro: considerações sobre a evolução e desenvolvimento do município no Brasil. 2010. 51f. Monografia. Curso de Direito.

Universidade Vale do Rio Doce - Faculdade de Direito, Ciências Administrativas e Econômicas - FADE, Governador Valadares, Minas Gerais, 2010. Disponível em:

http://www.pergamum.univale.br/pergamum/tcc/Federalismobrasileiroconsideracoessobreaevol ucaoedesenvolvimentodomunicipionobrasil.pdf. Acesso em: 02 de mar. 2017.

FERREIRA, Waldemar Martins. História do Direito Constitucional Brasileiro. Brasília: Senado Federal Conselho Editorial, 2003.

FURTADO, Celso. O longo amanhecer: reflexões sobre a formação do Brasil. Rio de Janeiro: Paz e Terra, 1999.

GUERRA, Daniele Marie. Descentralização e regionalização da assistência à saúde no estado de São Paulo: Uma análise do índice de dependência. 2015. 209 f. Tese (Doutorado em Saúde Pública). Universidade de São Paulo, São Paulo/SP, 2015. Disponível em:

http://www.teses.usp.br/teses/disponiveis/6/6135/tde-16112015-112549/pt-br.php. Acesso em: 02 de jun. 2017.

GUSTIN, Miracy Barbosa de Sousa. DIAS, Maria Tereza Fonseca. (Re) pensando a pesquisa jurídica: teoria e prática. Belo Horizonte: Del Rey, 2002.

HONORIO, Antônio Gonçalves. Concretização do direito internacional tributário por meio da aplicação do federalismo como princípio estruturante da nova ordem internacional. 2012. 104f. Dissertação (Mestrado em Direito Internacional Econômico). Pontifícia Universidade Católica de Brasília. Brasília/ DF, 2012. Disponível em: http://www.funag.gov.br/ipri/btd/index.php/10-dissertacoes/3679-concretizacao-do-direitointernacional-tributario-por-meio-da-aplicacao-do-federalismo-como-principio-estruturante-danova-ordem-internacional. Acesso em: 10 de jun. 2017.

HORTA, Raul Machado. As novas tendências do federalismo e seus reflexos na Constituição brasileira de 1988. Revista do Legislativo, n.25, jan./mar., p.14-24,1999. Disponível em: https://www.almg.gov.br/export/sites/default/consulte/publicacoes_assembleia/periodicas/revist as/arquivos/pdfs/25/raul25.pdf. Acesso em: 02 de dez. 2016. 
LEVCOVITZ, E. \& LIMA, L. D. \& MACHADO, C. V. Política de saúde nos anos 90: relações intergovernamentais e o papel das Normas Operacionais Básicas. Ciência \& Saúde Coletiva, v.6, n.2, p. 269-291, 2001.

LAKATOS. Eva Maria. Métodos e técnicas de pesquisa social. 6. ed. São Paulo: Atlas, 2008 LÜDKE, M.; ANDRÉ, M.E.D.A. Pesquisa em educação: abordagens qualitativas. São Paulo, EPU, 1986.

MEIRELLES, Hely Lopes. Direito municipal brasileiro. 6. ed. rev. e atual. São Paulo: Malheiros, 1992.

NEME, Eliana Franco; ARAUJO, Luiz Alberto David. O Federalismo como sistema de proteção dos direitos fundamentais. In: RAMOS, Paulo Roberto Barbosa (Org.). Constituição e Federalismo no mundo globalizado. São Luís: EDUFMA, 2011. p. 127-141.

PEREIRA, Fabiana Augusta de Araújo. Tributação indutora e ICMS: impactos da fiscal no federalismo brasileiro. Dissertação (Mestrado em Direito). Universidade Federal de Pernambuco, Recife, 2015. Disponível em: http://repositorio.ufpe.br/bitstream/handle/12 3456789/14912/Disserta\%C3\%A7\%C3\%A3o\%20VF\%20_\%20Fabiana\%20Augusta\%20de\%2 0Ara\%C3\%BAjo\%20Pereira.pdf?sequence=1\&isAllowed=y. Acesso em: 20 de jan. 2017.

PIRES, Maria Coeli Simões. O município no federalismo brasileiro: constrangimentos e perspectivas. Cadernos da Escola do Legislativo. Belo Horizonte, v. 8, n. 13, p. 55-84, jan./dez. 2005.

RABAT, Márcio Nuno. A federação: centralização e descentralização do poder político no Brasil. Consultoria Legislativa. Câmara dos Deputados. Estudo. Ago./2002. Disponível em: http://bd.camara.leg.br/bd/handle/bdcamara/1460. Acesso em: 22 de jan. 2017.

RAMOS, Paulo Roberto Barbosa. Federalismo e descentralização territorial em perspectiva comparada: Os sistemas do Brasil e da Espanha. Porto Alegre: Sergio Antonio Fabris, 2012.

REVERBEl, Carlos Eduardo Dieder. O Federalismo numa visão tridimensional do Direito. Porto Alegre: Livraria do Advogado, 2012.

RIOS, Ricardo Bahia. Resgatando a origem do federalismo moderno: o caso brasileiro e seus reflexos na gestão municipal. Revista Caminhos da Geografia, Uberlândia, v. 15, n. 52, p. 162-172, dez. 2014. Disponível em: http://www.seer.ufu.br/index.php/caminh osdegeografia/. Acesso em: 02 de mar. 2017.

ROCHA, Carmem Lúcia Antunes. República e federação no Brasil: traços constitucionais da organização política brasileira. Belo Horizonte: Del Rey, 1997.

SANTOS, Ronaldo Alencar dos; ANDRADE, Priscilla Lopes. A evolução histórica do federalismo brasileiro: Uma análise histórico-sociológica a partir das Constituições Federais. XXI Encontro Nacional do CONPEDI. 1ed. Florianópolis: Fundação Boiteux, 2012, v. XXI, p. 8-14794. Disponível em: http://www.publicadireito.com.br/artigos/?cod=a424ed4bd3a7d 6ae>. Acesso em 30 de jan. 2017.

SANTIN, Janaína Rigo; FLORES, Deborah Hartmann. A evolução histórica do município no federalismo brasileiro, o poder local e o estatuto da cidade. Revista Justiça do Direito, v. 20, n. 1, Passo Fundo, 2006, p. 56-69. Disponível em: http://www.seer.upf.br/index.ph p/rjd/article/ view/2176/1407. 
SCHMITT, Carl. Teoría de la Constitución. Tradução de Francisco Ayala. 1. ed. 1. reimp. Madrid: Alianza Editorial, 1992.

SCHMITT, Carl. O guardião da Constituição. Trad. Geraldo de Carvalho. Belo Horizonte: Del Rey, 2007.

SIQUEIRA, Luiza Noronha. Estado Federal, Tributação e Autonomia dos entes federados: possibilidade de fortalecimento do federalismo pela centralização. Dissertação (Mestrado em Direito). Pontifícia Universidade Católica de São Paulo. São Paulo, 2015. Disponível em: https://sapientia.pucsp.br/handle/handle/6863. Acesso em: 22 de dez. 2016.

SILVA, José Afonso da. Curso de direito constitucional positivo. 18. ed. São Paulo: Malheiros: 2000.

SOUZA, Adalberto Pimentel Diniz. A mecânica do federalismo. Revista de Informação Legislativa, Brasília, v. 42, n. 165, jan./ mar., p.169-176, 2005.

TAVARES, Iris Eliete Teixeira Neves de Pinho. O município brasileiro: sua evolução histórico constitucional. Revista de Direito Administrativo, Rio de Janeiro, v. 209, p. 169-187, jul./set. 1997. Disponível em: http://bibliotecadigital.fgv.br/ojs/index.php/rda/article/vi ew/47050.

TOMIO, Fabricio Ricardo de Limas. Federalismo, municípios e decisões legislativas: a criação de municípios no Rio Grande do Sul. Revista de Sociologia e Política, Curitiba, n. 24, jun.2005, p. 123-141. Disponível em: http://www.redalyc.org/articulo.oa?id=23802409. Acesso em: 20 de jun. 2018.

Artigo recebido em: 2019-08-06

Artigo reapresentado em: 2020-03-04

Artigo aceito para publicação em: 2020-03-10 